\title{
Article \\ Experimental Investigation of the Phase Relations in the Fe-Zr-Y Ternary System
}

\author{
Chenbo Li, Qian Song, Xianwen Yang, Yuduo Wei, Qi Hu, Libin Liu and Ligang Zhang *
}

Citation: Li, C.; Song, Q.; Yang, X.; Wei, Y.; Hu, Q.; Liu, L.; Zhang, L. Experimental Investigation of the Phase Relations in the Fe-Zr-Y

Ternary System. Materials 2022, 15, 593. https://doi.org/10.3390/ ma15020593

Academic Editor:

Carlos Garcia-Mateo

Received: 15 December 2021

Accepted: 11 January 2022

Published: 13 January 2022

Publisher's Note: MDPI stays neutral with regard to jurisdictional claims in published maps and institutional affiliations.

Copyright: (c) 2022 by the authors. Licensee MDPI, Basel, Switzerland. This article is an open access article distributed under the terms and conditions of the Creative Commons Attribution (CC BY) license (https:/ / creativecommons.org/licenses/by/ $4.0 /)$.
School of Material Science and Engineering, Central South University, Changsha 410083, China; 193112081@csu.edu.cn (C.L.); 203111046@csu.edu.cn (Q.S.); 213112124@csu.edu.cn (X.Y.); ol1fs5bov1e@163.com (Y.W.); 203112137@csu.edu.cn (Q.H.); pdc@csu.edu.cn (L.L.)

* Correspondence: ligangzhang@csu.edu.cn; Tel.: +86-182-2949-3731 or +86-0731-8887-7732
Abstract: The phase relations of the Fe-Zr-Y system at $973 \mathrm{~K}$ and $1073 \mathrm{~K}$ were experimentally investigated by using the equilibrated alloys. New ternary compounds $\tau 3-\mathrm{Fe}_{3} \mathrm{ZrY}$ and $\tau 4-\mathrm{Fe}_{10} \mathrm{Zr}_{5} \mathrm{Y}_{2}$ were found in this ternary system. The solubility of $\mathrm{Y}$ in $\mathrm{Fe}_{2} \mathrm{Zr}$ was measured to be 3.5 at.\% and the third component can hardly dissolve in the other binary intermetallic phases. Experiments have verified that $\mathrm{Fe}_{2.9} \mathrm{Zr}_{0.5} \mathrm{Y}_{0.5}$ has a solid solubility ranging from Fe73Zr12Y14 to Fe77Zr9Y13.

Keywords: Fe-Zr-Y system; phase equilibria; solid solubility; isothermal section

\section{Introduction}

Due to the use of nuclear fusion and the third-generation nuclear fission reactors, zirconium-based alloys have been widely studied as important nuclear cladding materials [1-5]. This relies on their specific characteristics: excellent corrosion resistance, good mechanical properties, high resistance to radiation damage and a low cross section of capture for thermal neutrons [6]. The Fe-Zr-Y system is an important member of the zirconium-based nuclear cladding materials, the high temperature resistance and radiation resistance of which can be greatly improved after oxidation [7-11]. Although the Fe-Zr-Y system has excellent prospects, there are still some problems that limit its applications in industry. For example, when the temperature of a nuclear reactor core continuously rises, the Fe-Zr-Y system may be at risk of being unstable [12].

An efficient and effective solution to this problem is to obtain a comprehensive and profound understanding on phases of different components and rule out the phases that are unstable at high temperatures in advance. which is of vital importance for the applications of the Fe-Zr-Y system [13]. The purpose of this work is to explore the phase diagram of the Fe-Zr-Y system at high temperature in order to intuitively express the relationship between phases under the thermodynamic equilibrium state so as to provide a basic theoretical guide for the research, development, and design of new materials.

The experimental investigations on the phase relations of the Fe-Zr-Y system [14-20] have been carried out, and several assessments of thermodynamic data have been obtained [21-26]. Although there are some controversies about the stability of hex- $\mathrm{Fe}_{2} \mathrm{Zr}$ and $\mathrm{Fe}_{23} \mathrm{Zr}_{6}$, it is widely accepted that both of the two phases exist [3]. According to the results of X-ray and magnetic measurements, Kai et al. [27] confirmed the presence of hexagonal $\mathrm{Fe}_{2} \mathrm{Zr}$, which had the same structure of $\mathrm{MgNi}_{2}$. Subsequently, Stein et al. [28] found the $\mathrm{Fe}_{2} \mathrm{Zr}$ phase of C36-type structure through heat treatment at $1563 \mathrm{~K}$. Meanwhile, Liu et al. [16] confirmed the existence of $\mathrm{Fe}_{23} \mathrm{Zr}_{6}$ by using a transmission electron microscope (TEM) and a scanning transmission electron microscope (STEM). Recently, Yang et al. [29] and Lu et al. [30] applied first-principles calculations to evaluate the formation enthalpy of compounds in $\mathrm{Fe}-\mathrm{Zr}$ system, in which $\mathrm{Fe}_{23} \mathrm{Zr}_{6}$ was considered as a stable phase. After a thorough survey and thermodynamic evaluations based on a number of experiments, the binary phase diagrams reported by Lu et al. [30] were finally adopted in 
this work. As shown in Figure 1, among the four intermetallic phases, only $\mathrm{Fe}_{2} \mathrm{Zr}$ phase has an obvious homogeneity range. In other phases, $\mathrm{FeZr}_{2}$ appears in the temperature range of $1215-1054 \mathrm{~K}$, and $\mathrm{FeZr}_{3}$ is formed through peritectoid reaction.

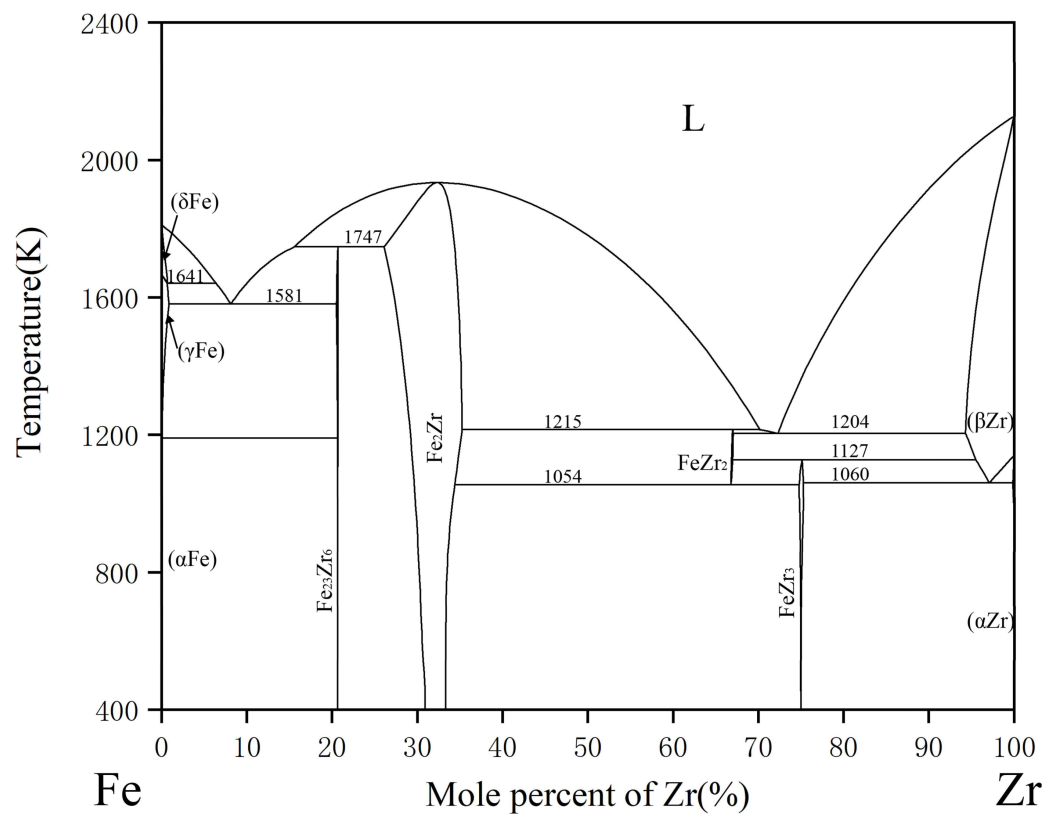

Figure 1. The calculated Fe-Zr phase diagram based on the work of Lu et al. [30].

Domagala et al. [31] reported the Fe-Y phase diagram for the first time in the whole composition range. Then, a thermodynamic assessment was carried out by Gschneider et al. [32] Recently, Zhang et al. studied the crystallography and thermodynamics of the compounds in the system, which provided a basis for further optimization of the Fe-Y system [33]. Figure 2 shows the Fe-Y phase diagram with four intermetallic compounds: $\mathrm{Fe}_{17} \mathrm{Y}_{2}, \mathrm{Fe}_{23} \mathrm{Y}_{6}, \mathrm{Fe}_{3} \mathrm{Y}$ and $\mathrm{Fe}_{2} \mathrm{Y}$. Based on the previous research work mentioned above, Saenko et al. [34] reported the thermodynamic optimization of the Fe-Y binary system, as shown in Figure 2.

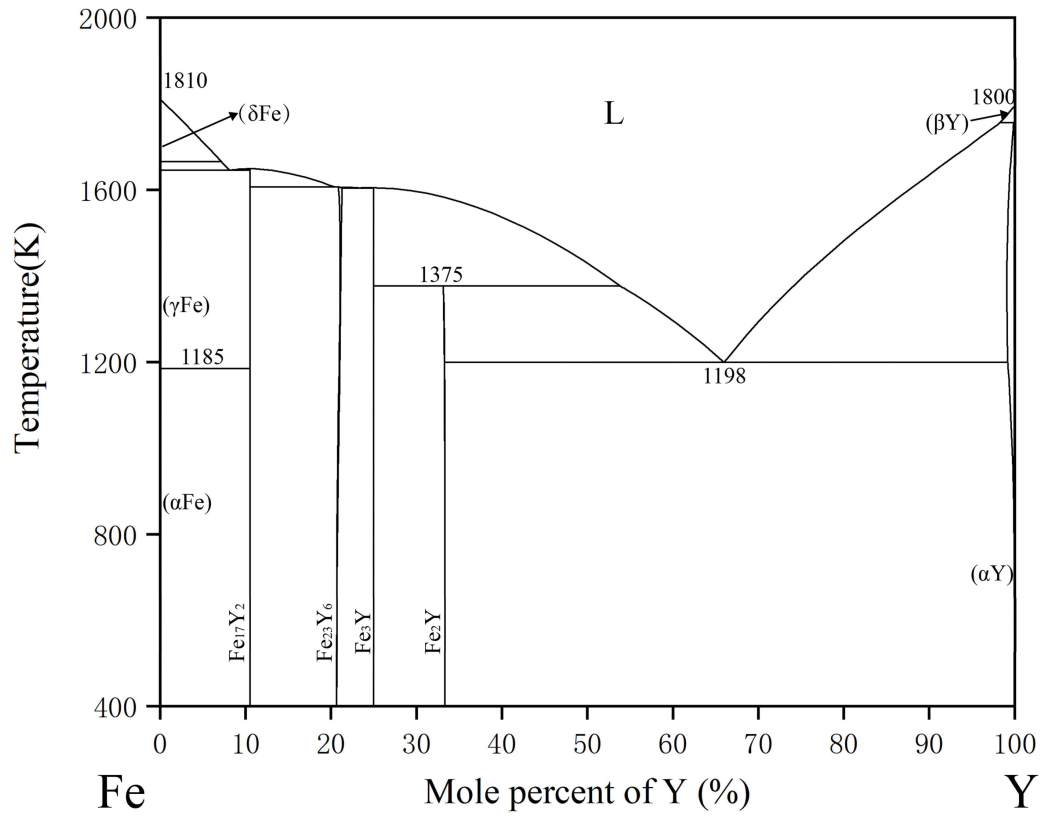

Figure 2. The calculated Fe-Y phase diagram based on the work of Saenko et al. [34]. 
The phase equilibrium relation of Zr-Y phase diagram was first studied by Wang [35], based on which Palenzona and Ciraflci [36] optimized the thermodynamic data. Recently, Flandorfer et al. [37] constructed the thermodynamic database of Zr-Y system. The calculated phase diagram used in this work adopts the latest thermodynamic parameters reported by $\mathrm{Bu}$ et al. [38], as shown in Figure 3.

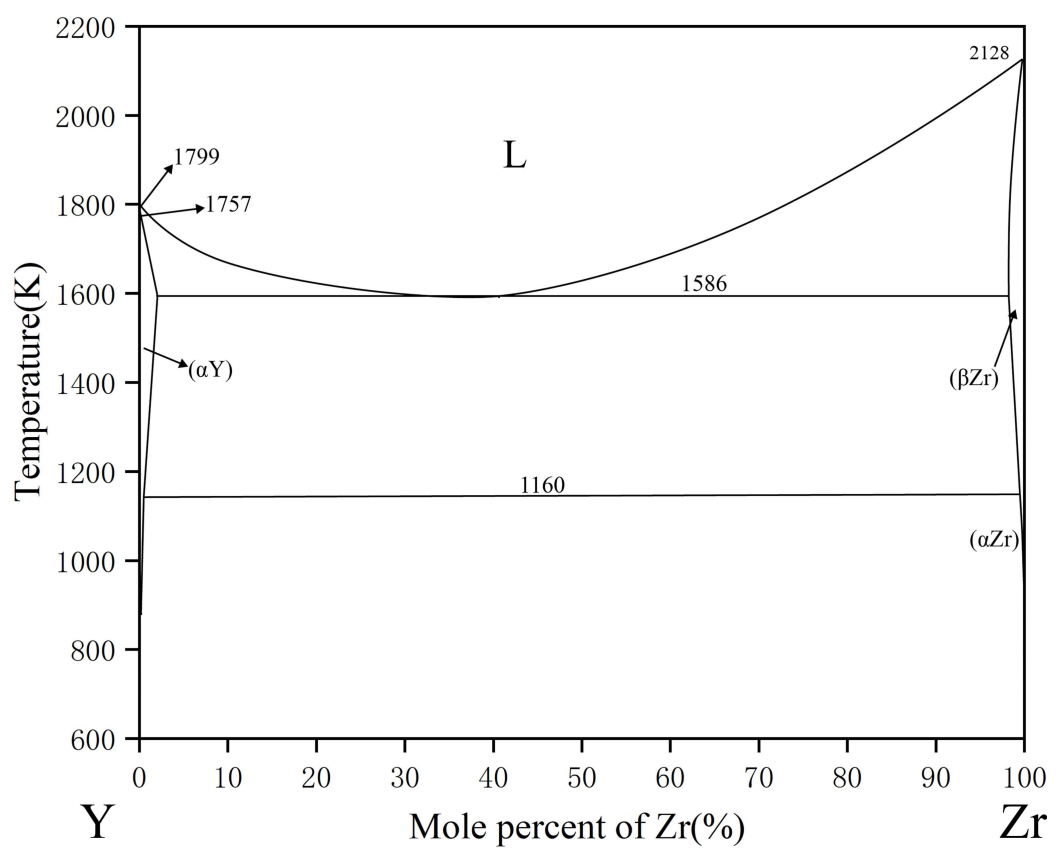

Figure 3. The calculated Y-Zr phase diagram based on the work of Bu et al. [38].

Research on the phase relationships and ternary compounds of Fe-Zr-Y ternary systems was relatively limited. In 1986, by combining three related binary phase diagrams, Harchenko et al. [39] measured the 1070K isothermal section of the Fe-Zr-Y ternary system for the first time, but no ternary compounds were discovered, as shown in Figure 4. In 1989, Jifan et al. reported $\mathrm{Fe}_{9} \mathrm{Zr}_{2} \mathrm{Y}$ phase with $\mathrm{ThMn}_{12}$ structure [40]. At the same time, Itoh et al. also found $\mathrm{Fe}_{2.9} \mathrm{Zr}_{0.5} \mathrm{Y}_{0.5}$ phase of Orthorhombic type [41]. The binary and ternary phases, the crystal structure and lattice parameters that were previously reported are listed in Table 1.

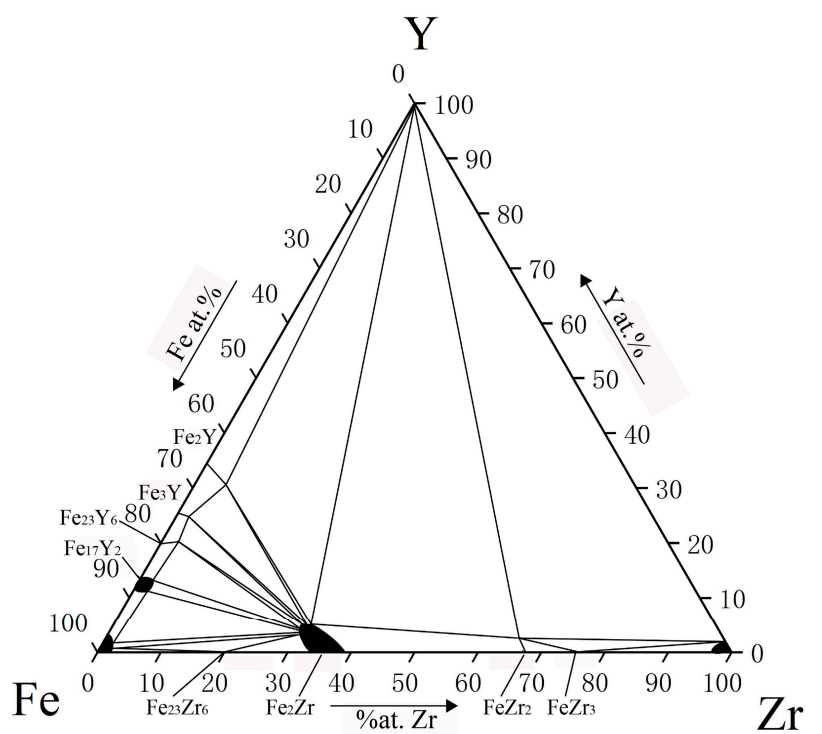

Figure 4. The $1070 \mathrm{~K}$ isothermal section of the Fe-Zr-Y ternary system [39]. 
Table 1. Experimental and literature data on crystal structures and lattice parameters of the solid phases in the Fe-Zr-Y system.

\begin{tabular}{|c|c|c|c|c|c|c|}
\hline \multirow[t]{2}{*}{ Phase } & \multirow[t]{2}{*}{ Phase Prototype } & \multirow[t]{2}{*}{ Space Group } & \multicolumn{3}{|c|}{ Lattice Parameters (nm) } & \multirow[t]{2}{*}{ Reference } \\
\hline & & & $\mathbf{a}$ & $\mathbf{b}$ & c & \\
\hline$\alpha(\mathrm{Fe})$ & W & $\operatorname{Im} \overline{3} \mathrm{~m}$ & 0.29315 & / & / & {$[42]$} \\
\hline$\delta(\mathrm{Fe})$ & $\mathrm{W}$ & $\operatorname{Im} \overline{3} \mathrm{~m}$ & 0.29315 & / & / & [42] \\
\hline$\beta(\mathrm{Zr})$ & $\mathrm{W}$ & $\operatorname{Im} \overline{3} \mathrm{~m}$ & 0.3568 & / & / & [42] \\
\hline$\gamma(\mathrm{Fe})$ & $\mathrm{Cu}$ & $\mathrm{Fm} \overline{3} \mathrm{~m}$ & 0.36599 & / & / & [42] \\
\hline$\alpha(\mathrm{Zr})$ & $\mathrm{Mg}$ & $\mathrm{P} 63 / \mathrm{mmc}$ & 0.323178 & / & 0.514831 & [28] \\
\hline $\mathrm{Fe}_{2} \mathrm{Zr} \_\mathrm{C} 15$ & $\mathrm{MgCu}_{2}$ & $\mathrm{Fd} \overline{3} \mathrm{~m}$ & 0.702 & / & / & {$[28]$} \\
\hline $\mathrm{Fe}_{23} \mathrm{Zr}_{6}$ & $\mathrm{Mn}_{23} \mathrm{Th}_{6}$ & $\mathrm{Fm} \overline{3} \mathrm{~m}$ & 1.172 & / & / & [28] \\
\hline $\mathrm{FeZr}_{2}$ & $\mathrm{Al} 2 \mathrm{Cu}$ & $\mathrm{I} 4 / \mathrm{mcm}$ & 0.638 & / & 0.56 & [28] \\
\hline $\mathrm{FeZr}_{3}$ & $\mathrm{BRe}_{3}$ & $\mathrm{Cmcm}$ & 0.332 & 1.1 & 0.882 & [28] \\
\hline $\mathrm{Fe}_{17} \mathrm{Y}_{2}$ & $\mathrm{Th}_{2} \mathrm{Zn}_{17}$ & $\mathrm{R} \overline{3} \mathrm{~m}$ & 0.846 & / & 1.241 & [43] \\
\hline $\mathrm{Fe}_{23} \mathrm{Y}_{6}$ & $\mathrm{Th}_{6} \mathrm{Mn}_{23}$ & $\mathrm{Fm} \overline{3} \mathrm{~m}$ & 1.2082 & / & / & [43] \\
\hline $\mathrm{Fe}_{3} \mathrm{Y}$ & $\mathrm{PuNi}_{3}$ & $\mathrm{R} \overline{3} \mathrm{~m}$ & 0.515 & / & 2.46 & [43] \\
\hline $\mathrm{Fe}_{2} \mathrm{Y}$ & $\mathrm{MgCu}_{2}$ & $\mathrm{Fd} \overline{3} \mathrm{~m}$ & 7.363 & / & / & [43] \\
\hline $\mathrm{Fe}_{9} \mathrm{Zr}_{2} \mathrm{Y}$ & $\mathrm{ThMn}_{12}$ & $\mathrm{I} 4 / \mathrm{mmm}$ & 0.8662 & 0.8662 & 0.50226 & [40] \\
\hline $\mathrm{Fe}_{2.9} \mathrm{Zr}_{0.5} \mathrm{Y}_{0.5}$ & / & / & 0.5067 & 0.8634 & 2.451 & [41] \\
\hline
\end{tabular}

\section{Experimental Procedures}

The phase relationship of the Fe-Zr-Y system was studied through the equilibrium alloy method of static measurements. Iron rod (99.99 wt.\%), zirconium rod (99.99 wt.\%) and yttrium block (99.99 wt.\%) were selected as raw materials. The weight of the samples was controlled around $12 \mathrm{~g}$, with an error of $\pm 0.005 \mathrm{~g}$. The samples were placed in a non-expendable arc melting furnace with high purity argon atmosphere. At the same time, a sponge titanium button was added as the oxygen absorber to prevent oxidation. Each alloy button was melted for at least 4 times to ensure its uniformity. The alloy buttons were divided into two parts and sealed in the quartz tubes filled with argon. According to the reported heat treatment processes of similar systems [3], 60 and 90 days were set as the annealing times for $700{ }^{\circ} \mathrm{C}$ and $800{ }^{\circ} \mathrm{C}$, respectively. After annealing, the samples were quenched in cold water to preserve the microstructure at high temperature.

The morphology and phase compositions of the alloy were analyzed by electron probe microanalysis (EPMA, JAXA-8800R, JEOL, $15 \mathrm{kV}, 1 \times 10^{-8} \mathrm{~A}$, Tokyo, Japan). X-ray diffraction was employed (XRD, Rigaku d-max/2550 VB, Cu K, 40 kV, 250 mA, Tokyo, Japan) to analyze the crystal structure of typical alloys, with the scanning range of $10-90^{\circ}$ and a speed of $0.133^{\circ} / \mathrm{s}$. Backscattering electron (BSE) images of the alloy samples were acquired using a scanning electron microscope (SEM, TESCAN MIRA3 LMH, $15 \mathrm{kV}$, working distance of $15 \mathrm{~mm}$, Brno, The Czech Republic).

\section{Experimental Results}

Based on the phase equilibrium data of 24 alloy samples, the isothermal section of the Fe-Zr-Y ternary system at $973 \mathrm{~K}$ was determined for the first time, as shown in Figure 5. A total of 12 three-phase regions and 12 two-phase regions were measured. In this isothermal section, there are four ternary compounds, among which, $\tau 1, \tau 3$ and $\tau 4$ have solid solubility intervals, and seven binary compounds, three of which have solid solubility, which are $\mathrm{Fe}_{2} \mathrm{Zr}, \mathrm{FeZr}_{3}, \mathrm{Fe}_{2} \mathrm{Y}$. 


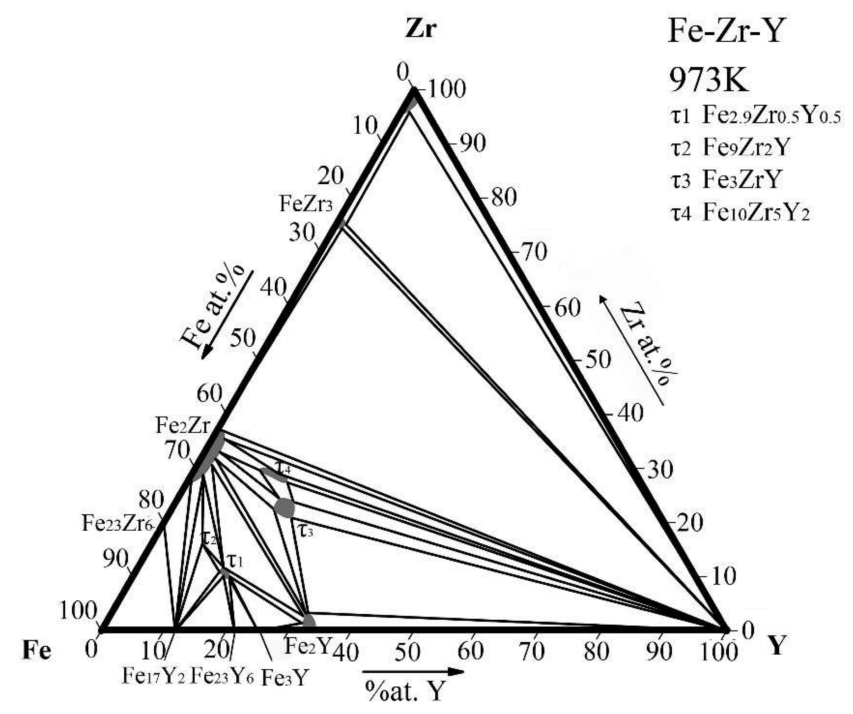

Figure 5. Isothermal section of the Fe-Zr-Y ternary system at $973 \mathrm{~K}$ determined in this work.

The isothermal section of Fe-Zr-Y ternary system at $1073 \mathrm{~K}$ is similar to the system at $973 \mathrm{~K}$ except that the maximum solid solubility of compounds $\tau 1$ and $\tau 3$ are slightly higher at $1073 \mathrm{~K}$. Additionally, $\mathrm{FeZr}_{2}$ as a high temperature phase appeared at $1073 \mathrm{~K}$. This is consistent with the binary optimized phase diagram, and therefore its appearance is reasonable and in accordance with expectation [30]. The $1073 \mathrm{~K}$ isothermal section obtained in this work is shown in Figure 6.

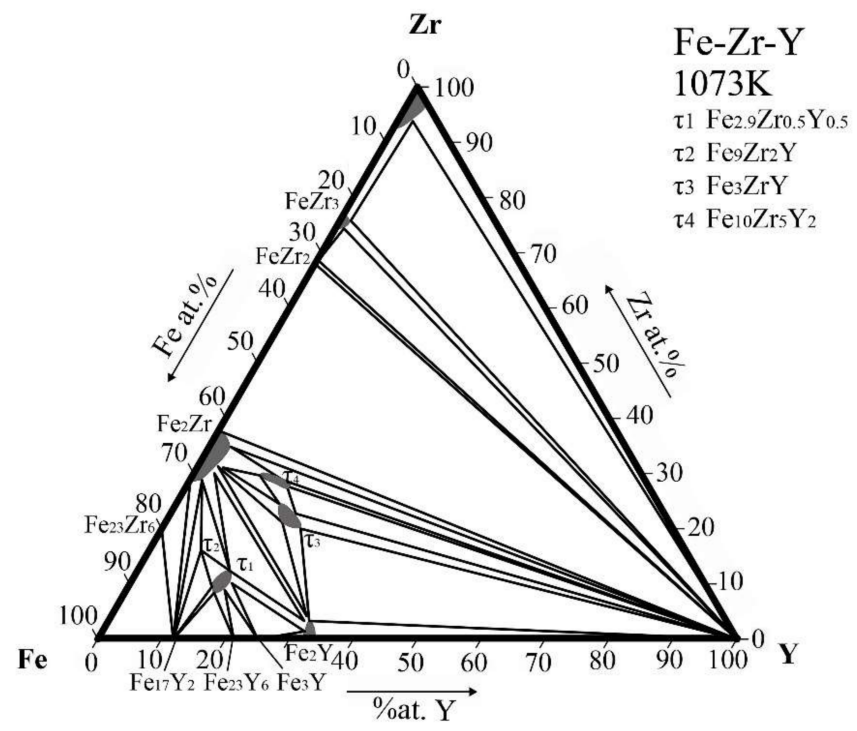

Figure 6. Isothermal section of the Fe-Zr-Y ternary system at $1073 \mathrm{~K}$ obtained in this work.

\section{Discussion}

The experimental data obtained from SEM, EPMA, XRD and EBSD examination were analyzed to determine the isothermal section and the phase relationship of the Fe-Zr-Y ternary system at $973 \mathrm{~K}$ and $1073 \mathrm{~K}$. The phase relations in several key alloys were discussed in detail as follows.

\subsection{Phase Equilibria at $973 \mathrm{~K}$}

A total of 24 alloy samples were prepared for the study of the phase equilibria of the Fe-Zr-Y ternary system at $973 \mathrm{~K}$. The constituent phases of each alloy sample were summarized in Table 2. 
Table 2. Constituent phases and compositions in the annealed Fe-Zr-Y alloys at $973 \mathrm{~K}$ for 90 days.

\begin{tabular}{|c|c|c|c|c|c|c|c|c|}
\hline \multirow{2}{*}{$\begin{array}{l}\text { Alloy } \\
\text { (No.) }\end{array}$} & \multirow{2}{*}{$\begin{array}{l}\text { Chemical } \\
\text { Composition }\end{array}$} & \multicolumn{3}{|c|}{ Nominal Composition (at.\%) } & \multicolumn{3}{|c|}{ Experimental Results (at.\%) } & \multirow{2}{*}{$\begin{array}{c}\text { Phase } \\
\text { Determination }\end{array}$} \\
\hline & & $\mathrm{Fe}$ & $\mathrm{Zr}$ & $\mathbf{Y}$ & $\mathrm{Fe}$ & $\mathrm{Zr}$ & $\mathbf{Y}$ & \\
\hline \multirow[t]{3}{*}{ A1 } & Fe10Zr70Y20 & 10 & 70 & 20 & 62.61 & 37.23 & 0.16 & $\mathrm{Fe}_{2} \mathrm{Zr}$ \\
\hline & & & & & 24.35 & 74.42 & 1.23 & $\mathrm{FeZr}_{3}$ \\
\hline & & & & & 0.29 & 0.13 & 99.58 & $\mathrm{Y}$ \\
\hline \multirow[t]{3}{*}{$\mathrm{A} 2$} & Fe60Zr30Y10 & 60 & 30 & 10 & 59.22 & 24.46 & 16.32 & $\tau 3$ \\
\hline & & & & & 59.77 & 29.61 & 10.62 & $\tau 4$ \\
\hline & & & & & 65.85 & 31.84 & 2.31 & $\mathrm{Fe}_{2} \mathrm{Zr}$ \\
\hline \multirow[t]{3}{*}{ A3 } & Fe10Zr60Y30 & 10 & 60 & 30 & 23.31 & 75.16 & 1.53 & $\mathrm{FeZr}_{3}$ \\
\hline & & & & & 2.81 & 95.82 & 1.37 & $\mathrm{Zr}$ \\
\hline & & & & & 98.87 & 0.15 & 0.98 & Y \\
\hline \multirow[t]{3}{*}{$\mathrm{A} 4$} & Fe77Zr16Y7 & 77 & 16 & 7 & 68.14 & 29.31 & 2.55 & $\mathrm{Fe}_{2} \mathrm{Zr}$ \\
\hline & & & & & 75.81 & 16.12 & 8.07 & $\tau 2$ \\
\hline & & & & & 88.24 & 0.21 & 11.55 & $\mathrm{Fe}_{17} \mathrm{Y}_{2}$ \\
\hline \multirow[t]{3}{*}{ A5 } & Fe80Zr4Y16 & 80 & 4 & 16 & 75.49 & 10.12 & 14.39 & $\tau 1$ \\
\hline & & & & & 78.74 & 0.28 & 20.98 & $\mathrm{Fe}_{23} \mathrm{Y}_{6}$ \\
\hline & & & & & 88.26 & 0.17 & 11.57 & $\mathrm{Fe}_{17} \mathrm{Y}_{2}$ \\
\hline \multirow[t]{3}{*}{ A6 } & Fe45Zr20Y35 & 45 & 20 & 35 & 57.34 & 23.89 & 18.77 & $\tau 3$ \\
\hline & & & & & 56.54 & 27.75 & 15.71 & $\tau 4$ \\
\hline & & & & & 0.21 & 0.16 & 99.63 & $\mathrm{Y}$ \\
\hline \multirow[t]{3}{*}{$\mathrm{A} 7$} & Fe50Zr10Y40 & 50 & 10 & 40 & 59.14 & 21.3 & 19.56 & $\tau 3$ \\
\hline & & & & & 99.54 & 0.16 & 0.30 & Y \\
\hline & & & & & 65.35 & 3.34 & 31.31 & $\mathrm{Fe}_{2} \mathrm{Y}$ \\
\hline \multirow[t]{3}{*}{ A8 } & Fe65Zr20Y15 & 65 & 20 & 15 & 65.86 & 31.84 & 2.30 & $\mathrm{Fe}_{2} \mathrm{Zr}$ \\
\hline & & & & & 61.11 & 22.54 & 16.35 & $\tau 3$ \\
\hline & & & & & 65.38 & 3.36 & 31.26 & $\mathrm{Fe}_{2} \mathrm{Y}$ \\
\hline \multirow[t]{3}{*}{ A9 } & Fe55Zr30Y15 & 55 & 30 & 15 & 62.51 & 35.48 & 2.01 & $\mathrm{Fe}_{2} \mathrm{Zr}$ \\
\hline & & & & & 57.17 & 29.6 & 13.23 & $\tau 4$ \\
\hline & & & & & 0.11 & 0.25 & 99.64 & $\mathrm{Y}$ \\
\hline A10 & Fe70Zr15Y15 & 70 & 15 & 15 & 74.62 & 11.77 & 13.61 & $\tau 1$ \\
\hline & & & & & 65.34 & 2.74 & 31.92 & $\mathrm{Fe}_{2} \mathrm{Y}$ \\
\hline & & & & & 66.54 & 30.86 & 2.60 & $\mathrm{Fe}_{2} \mathrm{Zr}$ \\
\hline A11 & Fe62Zr32Y6 & 62 & 32 & 6 & 65.13 & 33.11 & 1.76 & $\mathrm{Fe}_{2} \mathrm{Zr}$ \\
\hline & & & & & 59.35 & 30.36 & 10.29 & $\tau 4$ \\
\hline A12 & Fe20Zr60Y20 & 20 & 60 & 20 & 0.15 & 0.24 & 99.61 & Y \\
\hline & & & & & 23.59 & 74.42 & 1.99 & $\mathrm{FeZr}_{3}$ \\
\hline A13 & Fe61Zr25Y14 & 61 & 25 & 14 & 59.44 & 24.42 & 16.14 & $\tau 3$ \\
\hline & & & & & 65.87 & 31.82 & 2.31 & $\mathrm{Fe}_{2} \mathrm{Zr}$ \\
\hline A14 & FeZr74Y25 & 1 & 74 & 25 & 1.52 & 96.93 & 1.55 & $\mathrm{Zr}$ \\
\hline & & & & & 0.14 & 0.18 & 99.68 & $\mathrm{Y}$ \\
\hline A15 & Fe15Zr84Y & 15 & 84 & 1 & 1.19 & 95.92 & 2.89 & $\mathrm{Zr}$ \\
\hline & & & & & 23.21 & 75.96 & 0.83 & $\mathrm{FeZr}_{3}$ \\
\hline A16 & Fe29Zr70Y & 29 & 70 & 1 & 24.33 & 74.41 & 1.26 & $\mathrm{FeZr}_{3}$ \\
\hline & & & & & 62.45 & 37.44 & 0.11 & $\mathrm{Fe}_{2} \mathrm{Zr}$ \\
\hline A17 & Fe75Zr6Y19 & 75 & 6 & 19 & 74.71 & 9.69 & 15.6 & $\tau 1$ \\
\hline & & & & & 75.33 & 0.25 & 24.42 & $\mathrm{Fe}_{3} \mathrm{Y}$ \\
\hline & & & & & 78.75 & 0.33 & 20.92 & $\mathrm{Fe}_{23} \mathrm{Y}_{6}$ \\
\hline A18 & Fe55Zr30Y15 & 55 & 30 & 15 & 62.31 & 35.87 & 1.82 & $\mathrm{Fe}_{2} \mathrm{Zr}$ \\
\hline & & & & & 0.34 & 0.13 & 99.53 & $\mathrm{Y}$ \\
\hline A19 & Fe50Zr25Y25 & 50 & 25 & 25 & 56.25 & 27.91 & 15.84 & $\tau 4$ \\
\hline & & & & & 0.21 & 0.11 & 99.68 & Y \\
\hline A20 & Fe39ZrY60 & 39 & 1 & 60 & 65.45 & 1.86 & 32.69 & $\mathrm{Fe}_{2} \mathrm{Y}$ \\
\hline & & & & & 0.24 & 0.23 & 99.53 & $\mathrm{Y}$ \\
\hline A21 & Fe70ZrY29 & 70 & 1 & 29 & 66.87 & 0.16 & 32.97 & $\mathrm{Fe}_{2} \mathrm{Y}$ \\
\hline & & & & & 73.41 & 0.54 & 26.05 & $\mathrm{Fe}_{3} \mathrm{Y}$ \\
\hline A22 & Fe66Zr10Y24 & 66 & 10 & 24 & 65.66 & 2.74 & 31.6 & $\mathrm{Fe}_{2} \mathrm{Y}$ \\
\hline & & & & & 66.35 & 30.82 & 2.83 & $\mathrm{Fe}_{2} \mathrm{Zr}$ \\
\hline A23 & Fe4Zr8Y88 & 4 & 8 & 88 & 80.33 & 19.37 & 0.30 & $\mathrm{Fe}_{23} \mathrm{Zr}_{6}$ \\
\hline & & & & & 88.21 & 0.15 & 11.64 & $\mathrm{Fe}_{17} \mathrm{Y}_{2}$ \\
\hline & & & & & 98.56 & 0.74 & 0.70 & $\mathrm{Fe}$ \\
\hline A24 & Fe60Zr18Y22 & 60 & 18 & 22 & 65.39 & 3.18 & 31.43 & $\mathrm{Fe}_{2} \mathrm{Y}$ \\
\hline & & & & & 60.25 & 21.24 & 18.51 & $\tau 3$ \\
\hline
\end{tabular}

BSE images and XRD patterns of alloy samples A7, A13 and A24 are shown in Figure 7a,c,e). EPMA-WDS results show that the dark gray phases in A7, A13 and A24 have the same composition, close to Fe60Zr20Y20, so they are confirmed as the same phase. 
However, this composition is different from the existing ternary compounds in the Fe-Zr- $\mathrm{Y}$ system. For the further identification of this phase, XRD analysis was performed on all three samples. In the XRD patterns of the three alloys, there are unrecorded characteristic peaks, the positions of which are basically fixed. Only a few peaks have slight displacement, which may be due to the change in lattice parameters. According to the above analysis, the ternary compound was identified as a new phase with the chemical formula $\mathrm{Fe}_{3} \mathrm{ZrY}$ and named $\tau 3$. Since no single phase of $\tau 3$ was obtained in this work, follow-up experiments are needed to explore the crystal structure of $\tau 3$.
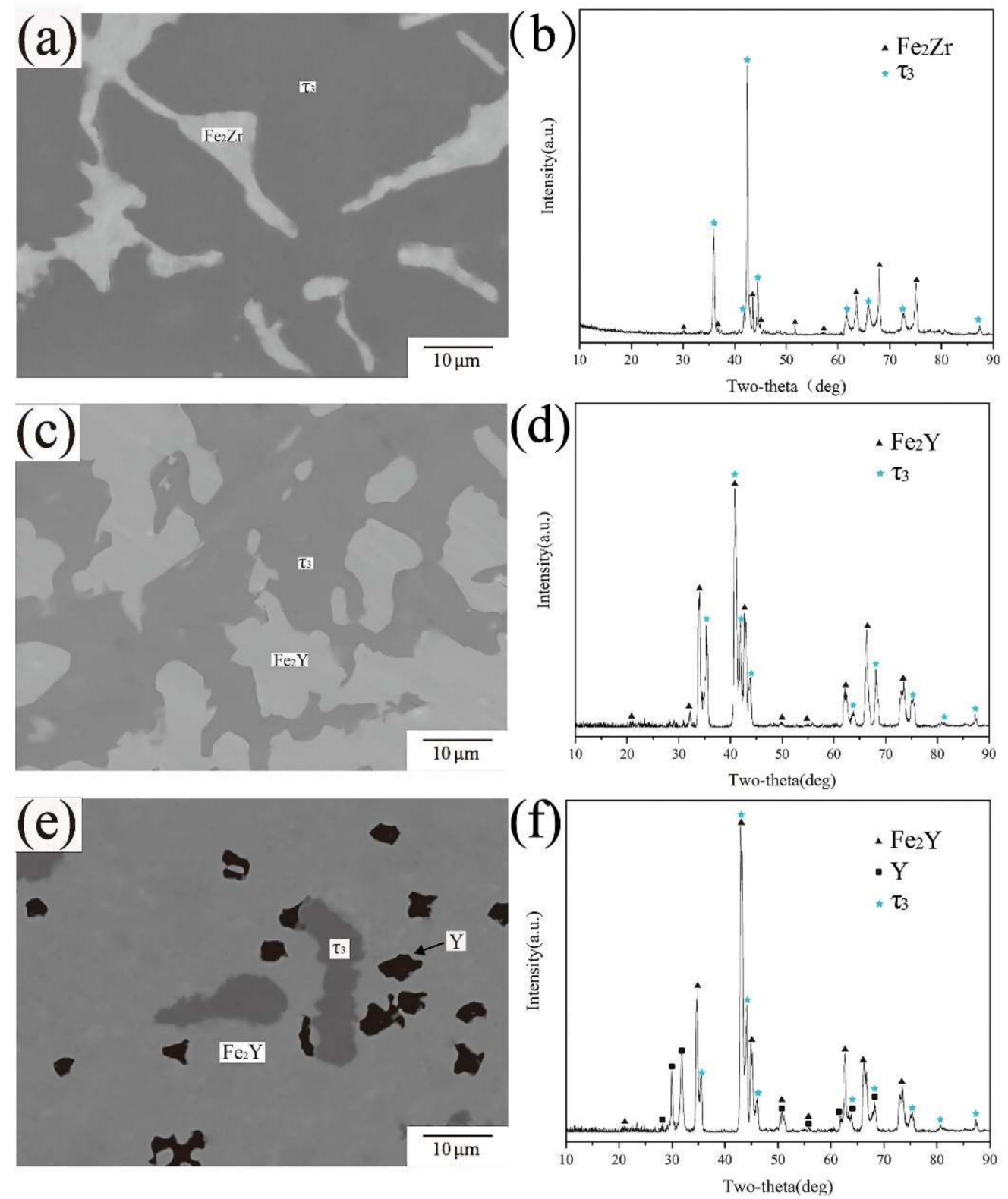

Figure 7. (a) BSE image of A13 (b) XRD pattern of A13 (c) BSE image of A1 of A24 (d) XRD pattern of A24 (e) BSE image of A7 (f) XRD pattern of A7.

There are three phases in the BSE images of alloy samples A2 and A9 (Figure 8a,c). According to the results of XRD and EPMA-WDS tests, all the phases are already identified except for the black phase. The compositions of the black phase in Figure 8a,c are Fe59.7Zr29.6Y10.5 and Fe56.2Zr27.9Y15.9, respectively. The stoichiometric ratios represent some differences between the two compositions, so the black phase was initially considered to be two different compounds. However, the XRD patterns (Figure $8 b, d$ ) show that the characteristic peaks of the two matched up, indicating that the crystal structures of the two 
phases were consistent, thus the two phases were confirmed to be the same compound. No ternary compound with similar stoichiometric ratio and diffraction peak matching was found in PDF cards. According to the results described above, the black phase was defined as the new ternary compound $\mathrm{Fe}_{10} \mathrm{Zr}_{5} \mathrm{Y}_{2}$ and named as $\tau 4$.
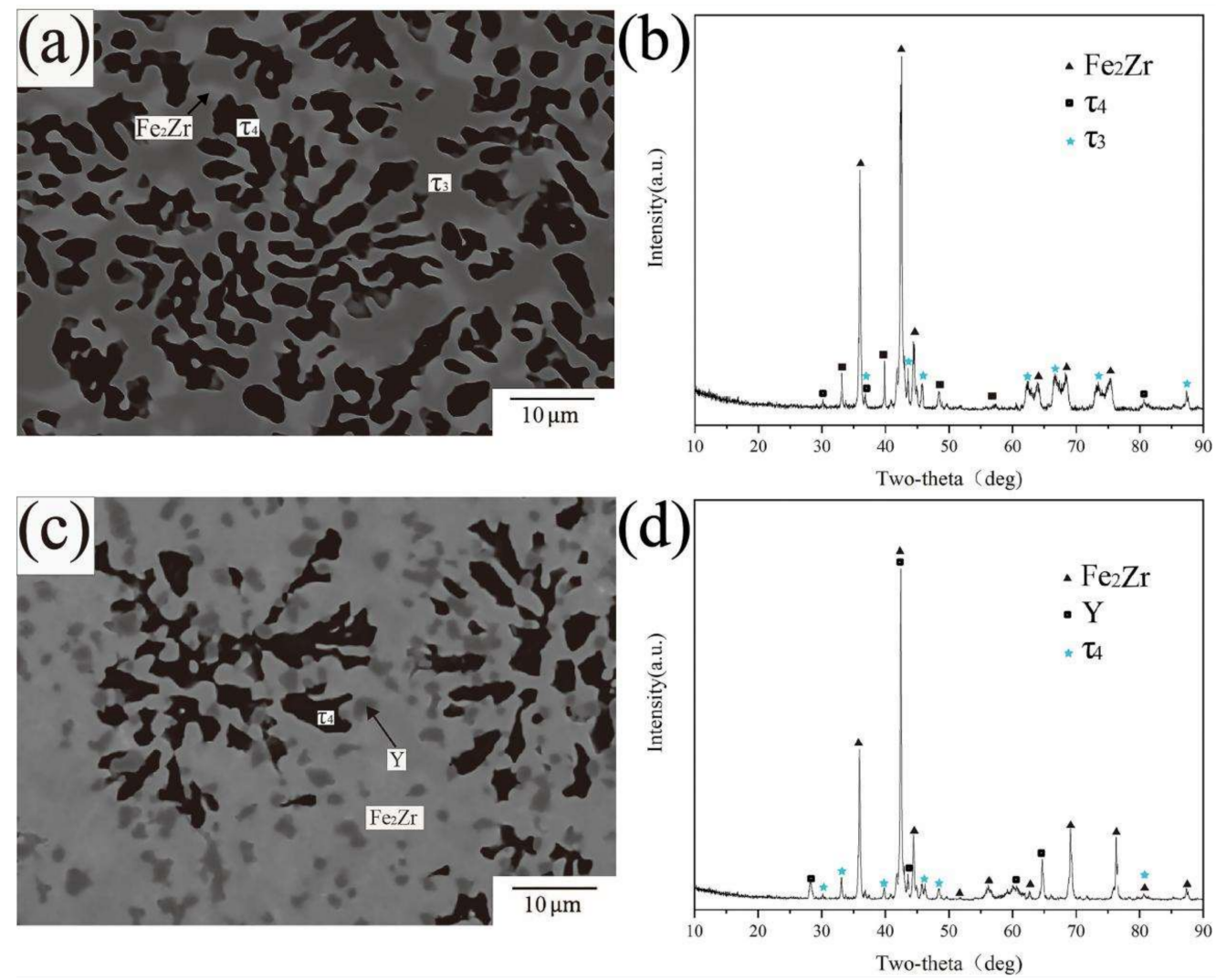

Figure 8. (a) BSE image of A2 (b) XRD pattern of A2 (c) BSE image of A9 (d) XRD pattern of A9.

The BSE images of alloy samples A5, A10 and A17 are shown in Figure 9a,c,e. The black phase in A10 and the dark gray phase in A5 and A17 have the same atomic ratio of $\mathrm{Fe}_{2.9} \mathrm{Zr}_{0.5} \mathrm{Y}_{0.5}$, which was denoted as $\tau 1$ phase. The XRD (as shown in Figure $9 \mathrm{~b}, \mathrm{~d}, \mathrm{f}$ ) characteristic peaks of compound $\tau 1$ have fixed positions, which are different from all the existing PDF cards. According to the reported literature [41], $\mathrm{Fe}_{2.9} \mathrm{Zr}_{0.5} \mathrm{Y}_{0.5}$ was considered to be transformed from $\mathrm{Fe}_{3} \mathrm{Y}$, as $\mathrm{Zr}$ atoms replaced $\mathrm{Y}$ atoms in $\mathrm{Fe}_{3} \mathrm{Y}$. In the study of Itoh et al. [41], $\mathrm{Fe}_{3} \mathrm{Y}$ did not exist in the $\mathrm{Fe}-\mathrm{Zr}-\mathrm{Y}$ system, as it was considered to be present in the form of $\mathrm{Fe}_{2.9} \mathrm{Zr}_{\mathrm{x}} \mathrm{Y}_{1-\mathrm{x}}(0 \leq \mathrm{x} \leq 1)$, meaning that $\mathrm{Y}$ would be replaced by $\mathrm{Zr}$ until $\mathrm{Y}$ disappears completely. This conclusion was not adopted in this work due to the following reasons: (1) $\mathrm{Fe}_{2.9} \mathrm{Zr}_{0.5} \mathrm{Y}_{0.5}$ would be adjacent to $\mathrm{Fe}_{3} \mathrm{Y}$ phase according to the reported theory [41], which is not consistent with what is shown in Figure 9a,c,e. Although there is $\mathrm{Fe}_{3} \mathrm{Y}$ shown in Figure $9 \mathrm{c}$, it is separated by $\mathrm{Fe}_{23} \mathrm{Y}_{6}$, and $\tau 1$ is completely wrapped by $\mathrm{Fe}_{23} \mathrm{Y}_{6}$ instead of $\mathrm{Fe}_{3} \mathrm{Y}$. (2) If $\mathrm{Fe}_{2.9} \mathrm{Zr}_{\mathrm{x}} \mathrm{Y}_{1-\mathrm{x}}(0 \leq \mathrm{x} \leq 1)$ phase exists, the solubility range of $\mathrm{Zr}$ in $\mathrm{Fe}_{3} \mathrm{Y}$ would pass through most of the phase equilibrium region, which violates the law of phase equilibrium relation. In conclusion, the phase $\mathrm{Fe}_{2.9} \mathrm{Zr}_{\mathrm{x}} \mathrm{Y}_{1-\mathrm{x}}(0 \leq \mathrm{x} \leq 1)$ is not adopted in this work. 

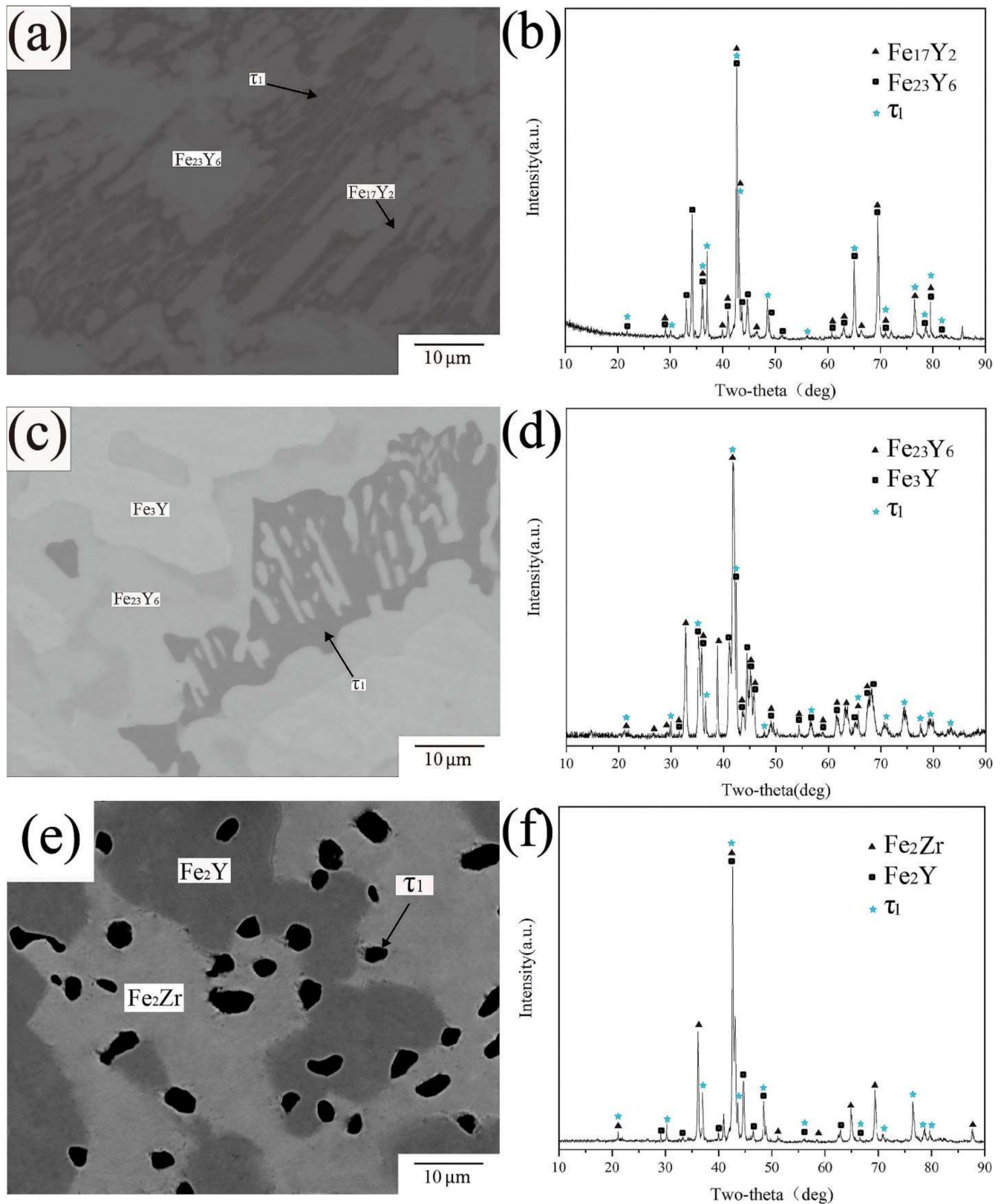

Figure 9. (a) BSE image of A5 (b) XRD pattern of A5 (c) BSE image of A17 (d) XRD pattern of A17 (e) BSE image of A10 (f) XRD pattern of A10.

BSE image Figure 10a illustrates the phase composition in alloy A4, which is composed of three phases. The results of EPMA-WDS show the continuously distributed matrix phase and the gray phase had the composition of Fe68.1Zr29.3Y2.6 and Fe88.2Y11.8, and were, respectively, determined as $\mathrm{Fe}_{2} \mathrm{Zr}$ and $\mathrm{Fe}_{17} \mathrm{Y}_{2}$ according to the XRD results of Figure 10b. The black phase labeled $\tau 2$ was presumed to be an unknown ternary compound at first, because the diffraction peaks cannot be matched by any PDF card corresponding to the crystal structure of the stable solid phase in the ternary system. However, they are indexed by a $\mathrm{ThMn}_{12}$ type crystal structure and obtain the characteristic peaks of $\mathrm{Fe}_{9} \mathrm{Zr}_{2} \mathrm{Y}$, which coincide with $\tau 2$ in the literature [40]. Therefore, $\tau 2$ phase was finally identified as the ternary compound $\mathrm{Fe}_{9} \mathrm{Zr}_{2} \mathrm{Y}$. 

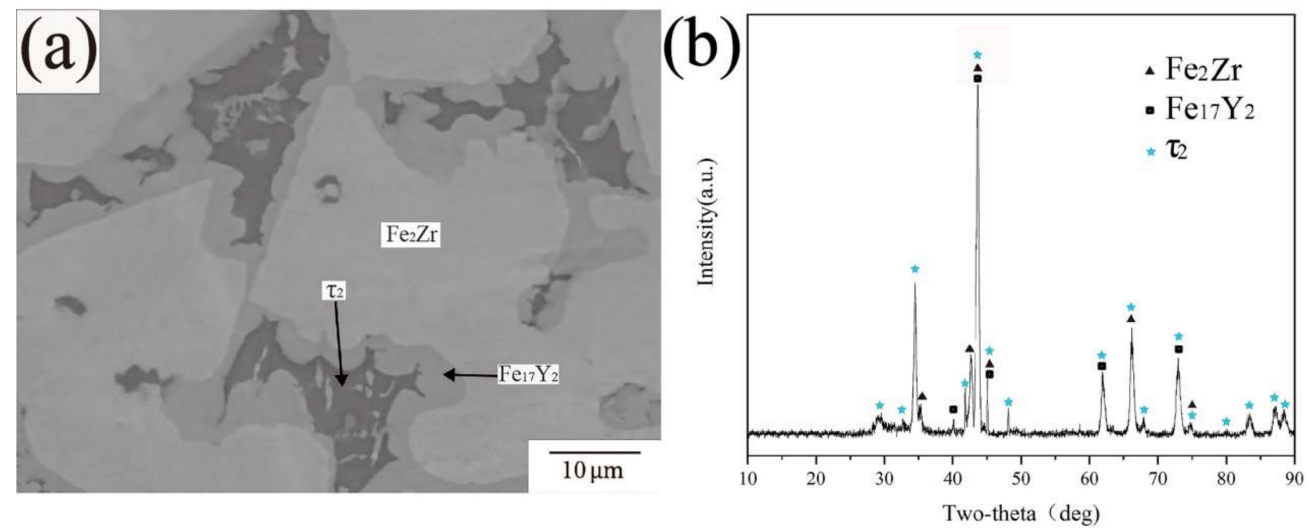

Figure 10. (a) BSE image of A4 (b) XRD pattern of A4.

Figure 11 shows the BSE images and XRD patterns of A16 and A18. According to the data from EPMA-WDS, the maximum atomic percentage of $\mathrm{Zr}$ in $\mathrm{Fe}_{2} \mathrm{Zr}$ is 37.6 at $973 \mathrm{~K}$ in A16. Combining Figure 11c with Figure 5, it can be seen that $Y$ tends to precipitate in the form of metal simple substance most of the time, which is in accord with the results obtained by Nouri et al. [38] Meanwhile, Y phase is dispersed, indented and porous, which can be mainly ascribed to the result of rapid galvanic corrosion of the $(\mathrm{Y})$, which acts as anode with Continuous-distributed matrix as cathode during polishing (or exposure to the moisture) [38].
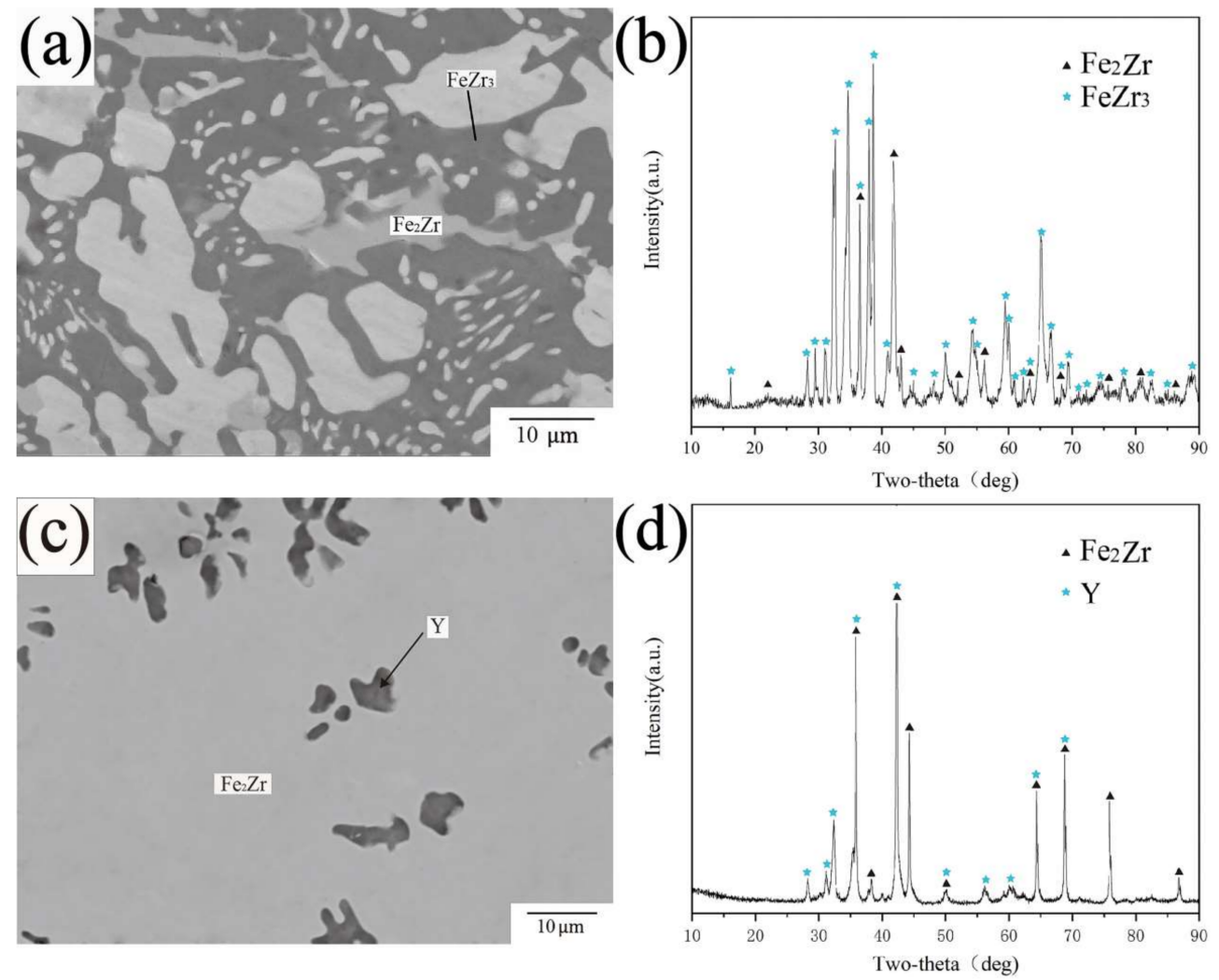

Figure 11. (a) BSE image of A16 (b) XRD pattern of A16 (c) BSE image of A18 (d) XRD pattern of A18.

\subsection{Phase Equilibria at $1073 \mathrm{~K}$}

The phase equilibrium of the Fe-Zr-Y ternary system at $1073 \mathrm{~K}$ was also investigated in this work. A total of 25 alloy samples were annealed at $1073 \mathrm{~K}$ for 60 days. The phases and compositions of each alloy are listed in Table 3. 
Table 3. Constituent phases and compositions in the annealed Fe-Zr-Y alloys at $1073 \mathrm{~K}$ for 60 days.

\begin{tabular}{|c|c|c|c|c|c|c|c|c|}
\hline \multirow{2}{*}{$\begin{array}{l}\text { Alloy } \\
\text { (No.) }\end{array}$} & \multirow{2}{*}{$\begin{array}{l}\text { Chemical } \\
\text { Composition }\end{array}$} & \multicolumn{3}{|c|}{ Nominal Composition (at.\%) } & \multicolumn{3}{|c|}{ Experimental Results (at.\%) } & \multirow{2}{*}{$\begin{array}{c}\text { Phase } \\
\text { Determination }\end{array}$} \\
\hline & & $\mathrm{Fe}$ & $\mathrm{Zr}$ & $\mathbf{Y}$ & $\mathrm{Fe}$ & $\mathrm{Zr}$ & $\mathbf{Y}$ & \\
\hline \multirow[t]{3}{*}{ B1 } & Fe10Zr70Y20 & 10 & 70 & 20 & 62.21 & 37.72 & 0.07 & $\mathrm{Fe}_{2} \mathrm{Zr}$ \\
\hline & & & & & 31.72 & 67.37 & 0.91 & $\mathrm{FeZr}_{2}$ \\
\hline & & & & & 0.13 & 0.21 & 99.66 & $\mathrm{Y}$ \\
\hline \multirow[t]{3}{*}{ B2 } & Fe60Zr30Y10 & 60 & 30 & 10 & 59.25 & 24.41 & 16.34 & $\tau 3$ \\
\hline & & & & & 59.73 & 29.66 & 10.61 & $\tau 4$ \\
\hline & & & & & 65.42 & 31.21 & 3.37 & $\mathrm{Fe}_{2} \mathrm{Zr}$ \\
\hline \multirow[t]{3}{*}{ B3 } & Fe10Zr60Y30 & 10 & 60 & 30 & 24.34 & 74.48 & 1.18 & $\mathrm{FeZr}_{3}$ \\
\hline & & & & & 93.86 & 3.84 & 2.3 & $\mathrm{Zr}$ \\
\hline & & & & & 0.35 & 0.13 & 99.52 & Y \\
\hline \multirow[t]{3}{*}{ B4 } & Fe77Zr16Y7 & 77 & 16 & 7 & 68.15 & 29.33 & 2.52 & $\mathrm{Fe}_{2} \mathrm{Zr}$ \\
\hline & & & & & 75.84 & 16.17 & 7.99 & $\tau 2$ \\
\hline & & & & & 88.25 & 0.16 & 11.59 & $\mathrm{Fe}_{17} \mathrm{Y}_{2}$ \\
\hline \multirow[t]{3}{*}{ B5 } & Fe80Zr4Y16 & 80 & 4 & 16 & 77.48 & 9.59 & 12.93 & $\tau 1$ \\
\hline & & & & & 78.77 & 0.27 & 20.96 & $\mathrm{Fe}_{23} \mathrm{Y}_{6}$ \\
\hline & & & & & 88.22 & 0.15 & 11.63 & $\mathrm{Fe}_{17} \mathrm{Y}_{2}$ \\
\hline \multirow[t]{3}{*}{ B6 } & Fe45Zr20Y35 & 45 & 20 & 35 & 57.63 & 22.74 & 19.63 & $\tau 3$ \\
\hline & & & & & 56.54 & 27.70 & 15.76 & $\tau 4$ \\
\hline & & & & & 0.12 & 0.25 & 99.63 & $\mathrm{Y}$ \\
\hline \multirow[t]{3}{*}{ B7 } & Fe50Zr10Y40 & 50 & 10 & 40 & 58.29 & 20.01 & 21.7 & $\tau 3$ \\
\hline & & & & & 0.35 & 0.16 & 99.49 & Y \\
\hline & & & & & 65.31 & 3.36 & 31.33 & $\mathrm{Fe}_{2} \mathrm{Y}$ \\
\hline B8 & Fe65Zr20Y15 & 65 & 20 & 15 & 65.47 & 31.28 & 3.25 & $\mathrm{Fe}_{2} \mathrm{Zr}$ \\
\hline & & & & & 60.55 & 21.16 & 18.29 & $\tau 3$ \\
\hline & & & & & 65.34 & 12.61 & 22.05 & $\mathrm{Fe}_{2} \mathrm{Y}$ \\
\hline B9 & Fe55Zr30Y15 & 55 & 30 & 15 & 61.89 & 34.82 & 3.29 & $\mathrm{Fe}_{2} \mathrm{Zr}$ \\
\hline & & & & & 56.68 & 28.8 & 14.52 & $\tau 4$ \\
\hline & & & & & 0.51 & 0.20 & 99.29 & $\mathrm{Y}$ \\
\hline B10 & Fe70Zr15Y15 & 70 & 15 & 15 & 73.14 & 12.48 & 14.38 & $\tau 1$ \\
\hline & & & & & 65.33 & 2.71 & 31.96 & $\mathrm{Fe}_{2} \mathrm{Y}$ \\
\hline & & & & & 66.59 & 30.65 & 2.76 & $\mathrm{Fe}_{2} \mathrm{Zr}$ \\
\hline B11 & Fe62Zr32Y6 & 62 & 32 & 6 & 63.23 & 32.45 & 4.32 & $\mathrm{Fe}_{2} \mathrm{Zr}$ \\
\hline & & & & & 10.28 & 30.79 & 58.93 & $\tau 4$ \\
\hline B12 & Fe20Zr60Y20 & 20 & 60 & 20 & 0.41 & 0.38 & 99.21 & Y \\
\hline & & & & & 1.73 & 75.2 & 23.07 & $\mathrm{FeZr}_{3}$ \\
\hline B13 & Fe61Zr25Y14 & 61 & 25 & 14 & 60.17 & 23.12 & 16.71 & $\tau 3$ \\
\hline & & & & & 65.54 & 31.35 & 3.11 & $\mathrm{Fe}_{2} \mathrm{Zr}$ \\
\hline B14 & FeZr74Y25 & 1 & 74 & 25 & 1.81 & 96.55 & 1.64 & $\mathrm{Zr}$ \\
\hline & & & & & 0.15 & 0.25 & 99.6 & $\mathrm{Y}$ \\
\hline B15 & Fe15Zr84Y & 15 & 84 & 1 & 0.87 & 94.83 & 4.3 & $\mathrm{Zr}$ \\
\hline & & & & & 22.61 & 76.52 & 0.87 & $\mathrm{FeZr}_{3}$ \\
\hline B16 & Fe29Zr70Y & 29 & 70 & 1 & 24.45 & 74.89 & 0.66 & $\mathrm{FeZr}_{3}$ \\
\hline & & & & & 31.31 & 68.61 & 0.08 & $\mathrm{FeZr}_{2}$ \\
\hline B17 & Fe75Zr6Y19 & 75 & 6 & 19 & 75.74 & 9.57 & 14.69 & $\tau 1$ \\
\hline & & & & & 75.31 & 0.36 & 24.33 & $\mathrm{Fe}_{3} \mathrm{Y}$ \\
\hline & & & & & 77.51 & 0.85 & 21.64 & $\mathrm{Fe}_{23} \mathrm{Y}_{6}$ \\
\hline B18 & Fe55Zr30Y15 & 55 & 30 & 15 & 61.94 & 36.13 & 1.93 & $\mathrm{Fe}_{2} \mathrm{Zr}$ \\
\hline & & & & & 0.10 & 0.21 & 99.69 & $\mathrm{Y}$ \\
\hline B19 & Fe50Zr25Y25 & 50 & 25 & 25 & 56.24 & 28.29 & 15.47 & $\tau 4$ \\
\hline & & & & & 0.32 & 0.15 & 99.53 & Y \\
\hline B20 & Fe39ZrY60 & 39 & 1 & 60 & 65.41 & 1.81 & 32.78 & $\mathrm{Fe}_{2} \mathrm{Y}$ \\
\hline & & & & & 0.14 & 0.32 & 99.54 & $\mathrm{Y}$ \\
\hline B21 & Fe70ZrY29 & 70 & 1 & 29 & 66.96 & 32.52 & 0.52 & $\mathrm{Fe}_{2} \mathrm{Y}$ \\
\hline & & & & & 75.06 & 0.10 & 24.84 & $\mathrm{Fe}_{3} \mathrm{Y}$ \\
\hline B22 & Fe66Zr10Y24 & 66 & 10 & 24 & 65.54 & 3.36 & 31.1 & $\mathrm{Fe}_{2} \mathrm{Y}$ \\
\hline & & & & & 66.11 & 30.91 & 2.98 & $\mathrm{Fe}_{2} \mathrm{Zr}$ \\
\hline B23 & Fe20Zr60Y20 & 20 & 60 & 20 & 22.95 & 75.47 & 1.58 & $\mathrm{FeZr}_{3}$ \\
\hline & & & & & 0.13 & 0.13 & 99.74 & $\mathrm{Y}$ \\
\hline & & & & & 31.20 & 68.64 & 0.16 & $\mathrm{FeZr}_{2}$ \\
\hline B24 & Fe84.5Zr12.5Y3 & 84.5 & 12.5 & 3 & 80.31 & 19.61 & 0.08 & $\mathrm{Fe}_{23} \mathrm{Zr}_{6}$ \\
\hline & & & & & 88.87 & 0.83 & 10.3 & $\mathrm{Fe}_{17} \mathrm{Y}_{2}$ \\
\hline & & & & & 99.15 & 0.17 & 0.68 & $\mathrm{Fe}$ \\
\hline B25 & Fe60Zr18Y22 & 60 & 18 & 22 & 65.32 & 3.37 & 31.31 & $\mathrm{Fe}_{2} \mathrm{Y}$ \\
\hline & & & & & 59.21 & 20.29 & 20.5 & $\tau 3$ \\
\hline
\end{tabular}


With the increase in temperature, the solid solubility region of $\tau 1$ and $\mathrm{Fe}_{2} \mathrm{Zr}$ becomes larger, and a new high temperature phase $\mathrm{FeZr}_{2}$ appears. This result is consistent with the binary phase diagram of Fe-Zr, but the exact formation temperature of $\mathrm{FeZr}_{2}$ had not been reported to date. The XRD pattern of B23 in Figure 12b shows the same characteristic peaks of $\mathrm{FeZr}_{2}$ as standard PDF cards. Combined with EPMA-WDS data, it can be seen that the dark phase in BSE image Figure 12a is the binary compound $\mathrm{FeZr}_{2}$.
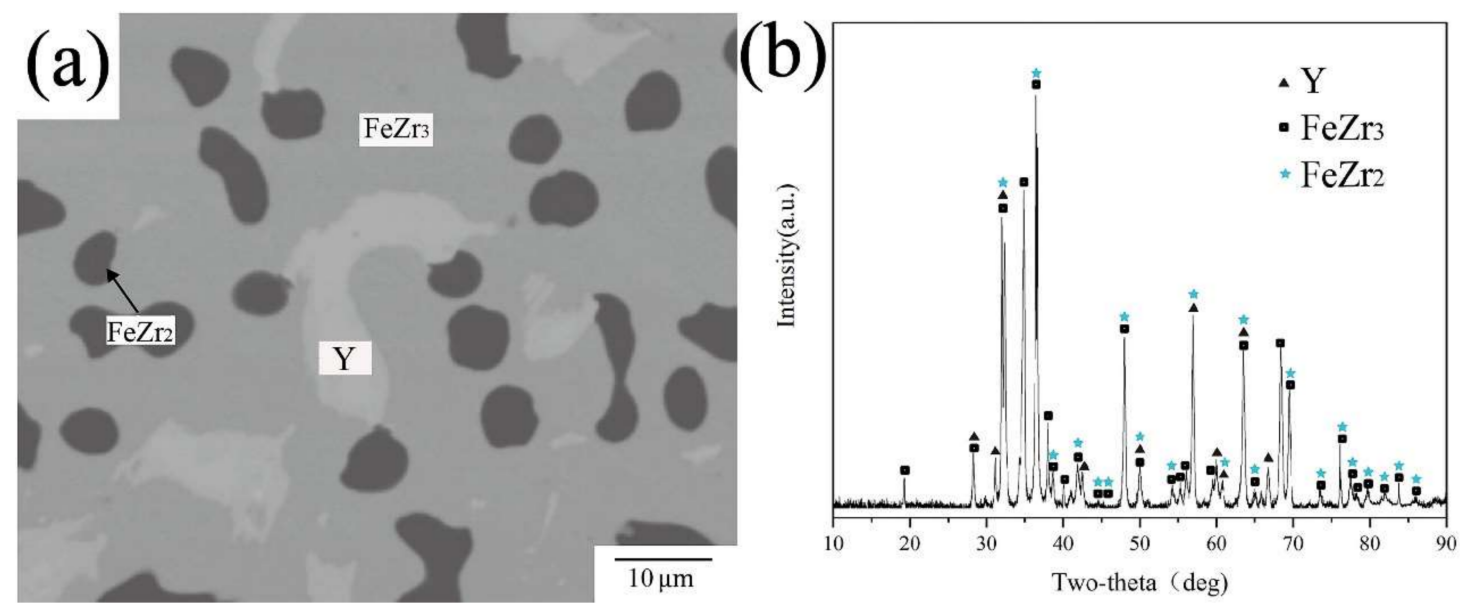

Figure 12. (a) BSE image of B23 (b) XRD pattern of B23.

\section{Conclusions}

In this work, the phase relationship of the Fe-Zr-Y ternary system at $973 \mathrm{~K}$ and $1073 \mathrm{~K}$ combined with EPMA-EDS, XRD and SEM results was studied systematically. There are twelve and thirteen three-phase regions measured at $973 \mathrm{~K}$ and $1073 \mathrm{~K}$, respectively. At $1073 \mathrm{~K}$, the solution ranges of $\tau 1-\mathrm{Fe}_{2.9} \mathrm{Zr}_{0.5} \mathrm{Y}_{0.5}$ are from Fe73Zr12Y14 to Fe77Zr9Y13. The maximum solid solubility of $\mathrm{Y}$ in $\mathrm{Fe}_{2} \mathrm{Zr}$ is 4 at.\% and atomic ratio of $\mathrm{Fe}_{2} \mathrm{Zr}$ is from Fe62Zr38 to Fe71Zr29 at $1073 \mathrm{~K}$. New ternary compounds $\tau 3-\mathrm{Fe}_{3} \mathrm{ZrY}$ and $\tau 4-\mathrm{Fe}_{10} \mathrm{Zr}_{5} \mathrm{Y}_{2}$ were investigated. Those isothermal sections at $1073 \mathrm{~K}$ and $973 \mathrm{~K}$ provide the possibility of providing a thermodynamic description of the system through the CALPHAD method, allowing more reliable extrapolations of the Fe-Zr-Y system to be used in the nuclear industry.

Author Contributions: Conceptualization, L.Z. and C.L.; methodology, X.Y.; software, Q.H.; validation, Y.W.; formal analysis, C.L. and X.Y.; investigation, C.L. and Q.S.; resources, Q.S. and Q.H.; data curation, C.L.; writing-original draft preparation, Q.S.; writing-review and editing, C.L.; visualization, L.L.; supervision, L.Z.; project administration, L.Z.; funding acquisition, L.Z. All authors have read and agreed to the published version of the manuscript.

Funding: The work was financially supported by National MCF Energy R\&D Program of China (No. 2018YFE0306100), National Natural Science Foundation of China (No. 51871248) and Natural Science Foundation of Hunan Province, China (No. 2020JJ4739).

Institutional Review Board Statement: Not applicable.

Informed Consent Statement: Not applicable.

Data Availability Statement: Not applicable.

Conflicts of Interest: The authors declare no conflict of interest.

\section{References}

1. Celbová, L.; Ashcheulov, P.; Klimša, L.; Kopeček, J.; Dragounová, K.A.; Luštinec, J.; Macák, J.; Škoda, R.; Kratochvílová, I. Diamond Coating Reduces Nuclear Fuel Rod Corrosion at Accidental Temperatures: The Role of Surface Electrochemistry and Semiconductivity. Materials 2021, 14, 6315. [CrossRef]

2. Diniasi, D.; Golgovici, F.; Marin, A.H.; Negrea, A.D.; Fulger, M.; Demetrescu, I. Long-Term Corrosion Testing of Zy-4 in a LiOH Solution under High Pressure and Temperature Conditions. Materials 2021, 14, 4586. [CrossRef] 
3. Zou, N.; Lu, H.-J.; Liu, L.-L.; He, Y.-L.; Lu, X.-G. Experimental investigation of phase equilibria in the Fe-Hf-Zr system at $1173 \mathrm{~K}$ and 1373 K. Calphad 2021, 72, 102240. [CrossRef]

4. Zhang, H.; Du, Y.; Shen, Z.; Zhou, P.; Peng, Y.; Liu, S.; Kong, Y.; Rajkumar, V.B. Thermodynamic modeling and solidified microstructure in the Mo-Nb-Zr ternary system. Calphad 2019, 66, 101630. [CrossRef]

5. Zeng, Y.; Zhou, P.; Du, Y.; Mo, W.; Bai, B.; Wang, X.; Zhao, J. A thermodynamic description of the U-Ti-Zr system. Calphad 2018, 60, 90-97. [CrossRef]

6. Nieva, N.; Corvalán, C.; Jiménez, M.J.; Gómez, A.; Arreguez, C.; Joubert, J.M.; Arias, D. Phase diagram of the Fe-Sn-Zr system at $800{ }^{\circ}$ C. J. Nucl. Mater. 2017, 487, 186-191. [CrossRef]

7. Wang, Y.; Xu, S.; Jia, H.; Tong, Z.; Zhou, Z. Influence of Zr addition on the microstructure and mechanical properties of 9CrTi-ODS steels. Nucl. Mater. Energy 2021, 29, 101101. [CrossRef]

8. Gómez-Acebo, T. Summary report of CALPHAD XLII-San Sebastian, Spain, 2013. Calphad 2014, 45, 62-117. [CrossRef]

9. Li, Z.; Chen, L.; Zhang, H.; Liu, S. High-Temperature Oxidation Properties and Microstructural Evolution of Nanostructure Fe-Cr-Al ODS Alloys. Materials 2021, 14, 526. [CrossRef]

10. Zhou, X.; Li, G.; Shen, X.; Liu, Y. Tensile strength improvement of martensitic ODS steels with Zr and Hf additions. Mater. Sci. Eng. A 2022, 829, 142071. [CrossRef]

11. Peng, S.; Lu, Z.; Yu, L. Effects of $\mathrm{Y} 2 \mathrm{O} 3 / \mathrm{Ti} / \mathrm{Zr}$ addition on microstructure and hardness of ODS-CoCrFeNi HEAs produced by mechanical alloying and spark plasma sintering. J. Alloys Compd. 2021, 861, 157940. [CrossRef]

12. Chang, K.-C.; Zhao, J.-R.; Hung, F.-Y. Effects of hyper-high-temperature solid-solution treatment on microstructure evolution and nanoprecipitation of the Al-Ni-Cu-Fe-Zr-Sc alloy manufactured by selective laser melting. J. Alloys Compd. 2021, 883, 160781. [CrossRef]

13. Sundman, B.; Dupin, N.; Hallstedt, B. Algorithms useful for calculating multi-component equilibria, phase diagrams and other kinds of diagrams. Calphad 2021, 75, 102330. [CrossRef]

14. Malakhova, T.; Alekseyeva, Z. The Zr-Fe phase diagram in the range $20-40$ at. $\%$ Fe and the crystalline structure of the intermetallic compound Zr3Fe. J. Less Common Met. 1981, 81, 293-300. [CrossRef]

15. Raghavan, V. Al-Fe-Zr (Aluminum-Iron-Zirconium). J. Phase Equilibria Diffus. 2010, 31, 459-462. [CrossRef]

16. Liu, Y.; Allen, S.M.; Livingson, J.D. An investigation of Fe3Zr phase. Scr. Metall. Mater. 1995, 32, 1129-1132. [CrossRef]

17. Granovsky, M.S.; Canay, M.; Lena, E.; Arias, D. Experimental investigation of the $\mathrm{Zr}$ corner of theternary $\mathrm{Zr}-\mathrm{Nb}-\mathrm{Fe}$ phase diagram. J. Nucl. Mater. 2002, 302, 1-8. [CrossRef]

18. Zeng, L.; Xu, G.; Liu, L.; Bai, W.; Zhang, L. Experimental investigation of phase equilibria in the Ti-Fe-Zr system. Calphad 2018, 61, 20-32. [CrossRef]

19. Ye, J.; Guan, R.; Zhao, H.; He, C.; Xiong, K. Effect of Zr Microalloying on the Microstructures and Strengthening Mechanism of As-Cast Al-Fe-Zr Alloys. Materials 2020, 13, 4744. [CrossRef]

20. Malakhova, T.O.; Kobylkin, A.N. Phase diagram for Zr-Fe(0-66,6 at.\%Fe). Izvestiya Akademii Nauk SSSR Metally 1982, 14, $205-209$.

21. Servant, C.; Gueneau, C.; Ansara, I. Experimental and thermodynamic assessment of the Fe-Zr system. J. Alloys Compd. 1995, 220, 19-26. [CrossRef]

22. Saenko, I.; Kuprava, A.; Udovsky, A.; Fabrichnaya, O. Heat capacity measurement of Zr2Fe and thermodynamic re-assessment of the Fe-Zr system. Calphad 2019, 66, 101625. [CrossRef]

23. Jiang, M.; Oikawa, K.; Ikeshoji, T.; Wulff, L.; Ishida, K. Thermodynamic Calculations of Fe-Zr and Fe-Zr-C Systems. J. Phase Equilibria Diffus. 2000, 22, 406-417. [CrossRef]

24. Zou, N.; Lu, H.-J.; Gu, P.-W.; Wang, J.-Y.; Feng, X.-K.; Shen, J.-Y.; He, Y.-L.; Li, L.; Lu, X.-G. Thermodynamic assessment and glass forming ability prediction of the Zr-Fe-Cu system. Calphad 2019, 64, 175-184. [CrossRef]

25. Rigaud, V.; Sundman, B.; Daloz, D.; Lesoult, G. Thermodynamic assessment of the Fe-Al-Zr phase diagram. Calphad 2009, 33, 442-449. [CrossRef]

26. Cui, J.; Shen, Y.; Liu, X. Experimental investigation and thermodynamic modeling of the Fe-Si-Zr system. Calphad 2019, 65, 385-401. [CrossRef]

27. Kai, K.; Nakamichi, T.; Yamamoto, M. Crystal Structures and Magnetic Properties of the Intermetallic Compnd Fe 2 Zr. J. Phys. Soc. 1968, 25, 1192. [CrossRef]

28. Stein, F.; Sauthoff, G.; Palm, M. Experimental Determination of Intermetallic Phases, Phase Equilibria, and Invariant Reaction Temperatures in the Fe-Zr System. J. Phase Equilibria Diffus. 2002, 23, 480-494. [CrossRef]

29. Yang, Y.; Tan, L.; Bei, H.; Busby, J.T. Thermodynamic modeling and experimental study of the Fe-Cr-Zr system. J. Nucl. Mater. 2013, 441, 190-202. [CrossRef]

30. Lu, H.-J.; Zou, N.; Zhao, X.-S.; Shen, J.-Y.; Lu, X.-G.; He, Y.-L. Thermodynamic investigation of the Zr-Fe-Nb system and its applications. Intermetallics 2017, 88, 91-100. [CrossRef]

31. Domagala, R.F.; Rausch, J.J.; Levinson, D.W. The systems Y-Fe, Y-Ni, and Y-Cu. Trans. Am. Soc. Met. 1961, 53, 139-155.

32. Gschneidner, K.A., Jr. Rare Earth Alloys; D. Van Nostrand Company Inc.: Princeton, NJ, USA, 1961; Volume 60, p. 247.

33. Zhang, W.; Liu, G.; Han, K. The Fe-Y (iron-yttrium) system. J. Phase Equilibria 1992, 13, 304-308. [CrossRef]

34. Saenko, I.; Fabrichnaya, O.; Udovsky, A. New Thermodynamic Assessment of the Fe-Y System. J. Phase Equilibria Diffus. 2017, 38, 684-699. [CrossRef] 
35. Wang, R. Formation of metastable low temperature allotropie solid solutions in rare earth-zirconium systems. Metall. Trans. 1972, 3, 1213-1221. [CrossRef]

36. Palenzona, A.; Cirafici, S. The Y-Zr (yttrium-zirconium) system. J. Phase Equilibria 1991, 12, 485-489. [CrossRef]

37. Flandorfer, H.; Gröbner, J.; Stamou, A.; Hassiotis, N.; Saccone, A.; Rogl, P.; Wouters, R.; Seifert, H.; Macciò, D.; Ferro, R. Experimental investigation and thermodynamic calculation of the ternary system Mn-Y-Zr. Int. J. Mater. Res. 1997, 88, 529-538.

38. Bu, M.J.; Wang, P.S.; Xu, H.H.; Liu, S.H.; Sha, C.S.; Du, Y.; Pan, F.S.; Tang, A.T. Experimental investigation and thermodynamic modeling of the Zr-Y system. J. Min. Metall. Sect. B Metall. 2010, 46, 181-192. [CrossRef]

39. Harchenko, O.I.; Berezyuk, D.A.; Kryshtal, M.I. Ternary (Y,Ce)-Zr-Fe systems. Visn. L'vivs'kogo (Derzhavnogo) Univ. Seriya Khimichna 1984, 25, 26-28.

40. Jifan, H.; Mingxi, L.; Rufeng, X.; Shougong, Z.; Zhenxi, W. Formation of Magnetic Phases in Y-Zr-Fe Compounds. Phys. Stat. Sol. 1989, 113, 127-129.

41. Itoh, K.; Okagaki, T.; Kanematsu, K. Crystal Structure and Magnetic Properties of Y1-xZrxFe2.9. J. Phys. Soc. 1989, 58, 1787-1792. [CrossRef]

42. Villars, P. Pearson's Handbook Desk Edition: C. Data for Intermetallic Phases, volume 2. ASM Int. 1997, 1, 1143.

43. Nouri, K.; Jemmali, M.; Walha, S.; Salah, A.B.; Dhahri, E.; Bessais, L. Experimental investigation of the Y-Fe-Ga ternary phase diagram: Phase equilibria and new isothermal section at $800^{\circ} \mathrm{C}$. J. Alloys Compd. 2017, 719, 256-263. [CrossRef] 